\title{
POLYEMBRYONY AMONG ABIETINEAE
}

CÓNTRIBUTIONS FROM THE HULL BOTANICAL LABORATORY 261 JонN T. ВUСНноLZ

(WITH FIFTEEN FIGURES)

Polyembryony among conifers is of two kinds: cleavage polyembryony, in which a single fertilized egg gives rise to many embryos; and the simple polyembryony, which is due to plurality of archegonia. This latter form is encountered wherever there are several eggs that may be fertilized, and therefore is found among all gymnosperms. The fact that polyembryony was found in both the pines and the cycads, and was due to plurality of "corpuscula" or "areolae" (archegonia) in both instances, was one of the arguments presented by Brown $(\mathbf{I}, \mathbf{2})$ as early as 1826 as showing a fundamental relationship between these two groups.

A form like Pinus, which has cleavage polyembryony, usually has several eggs fertilized also, and therefore combines both forms of polyembryony. Since each zygote in Pinus usually gives rise to a system of 8 embryos, there may be as many embryos as 8 times the number of fertilized eggs. If all 6 of the archegonia of some species were fertilized, 48 embryos might be produced, but 4 is the maximum number of embryo systems that have actually been found, and even then many of the embryos disappear very early, some of the rosette embryos being aborted without division of the embryo initial cell.

In discussing polyembryony, it is necessary to consider briefly the pine proembryo stages, shown in the accompanying figures. The writer's interpretation of the facts brought out by various investigators, together with his own studies, would describe the initial steps in the development of the pine embryo as follows.

The zygote begins development with free nuclear divisions (figs. $\mathrm{I}-3$ ). When 4 free nuclei have been formed they descend to the bottom of the egg, and there undergo another free nuclear division, after which the primary embryo initial group of cells $(p)$ is 
cut off by complete walls from the rest of the cytoplasm of the egg. Each cell of this tier constitutes an initial cell to one of the 4 primary embryos. The tier above it is not completely walled, and therefore undergoes another free nuclear division, organizing the second tier of completely walled cells $(r)$, the rosette tier, a group of initial cells of the rosette embryos. The open tier of free nuclei $(o)$ which remain above this undergo no further division and soon disintegrate. When these 3 tiers of 8 walled cells and 4 free nuclei have formed, as in fig. 5, the organization stage of the proembryo is concluded, for each cell is now ready to produce its own distinct embryo, although the 4 cells of the primary embryo initial tier $(p)$ continue their further development in unison.
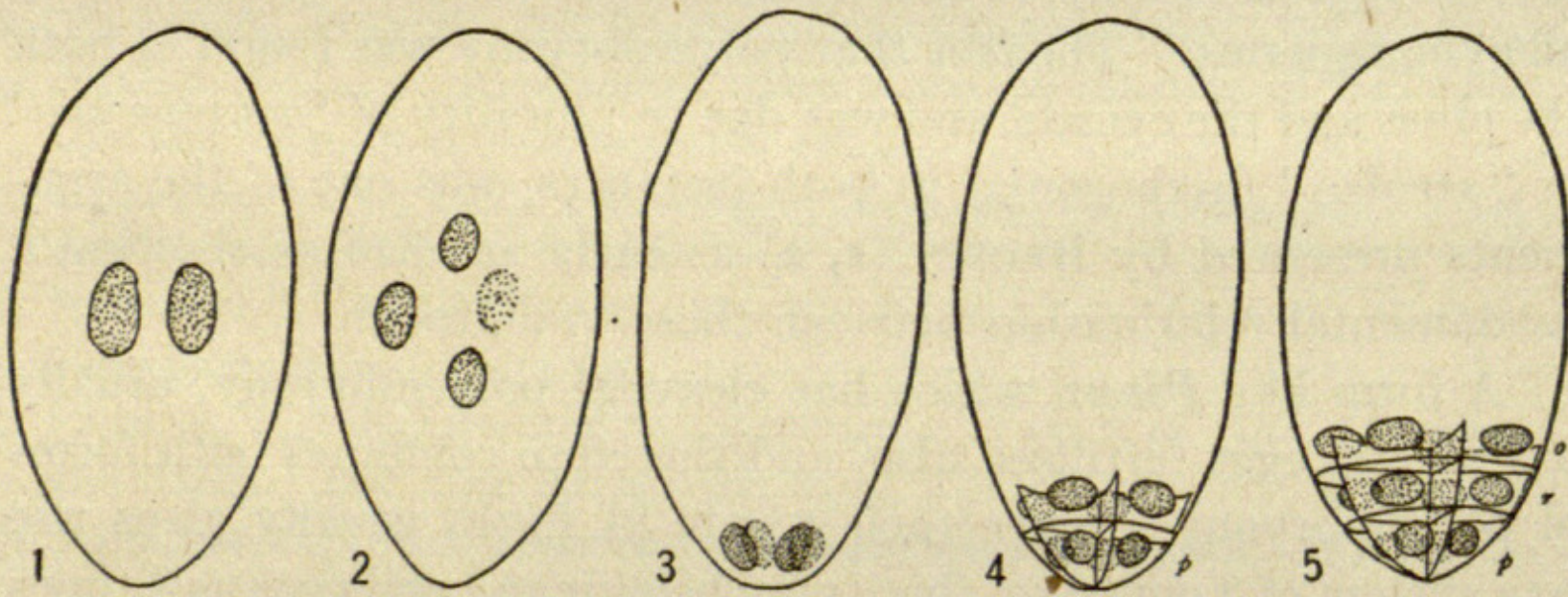

FIGs. I-5.-Steps in development of proembryo in Pinus, diagrammatic reconstructions from serial sections and published figures: $p$, tier of primary embryo initial cells; $r$, tier of rosette cells, initial cells of rosette embryos; $o$, upper open tier of cells; normally tiers $r$ and $o$ come from division (free nuclear) of upper tier of fig. 4 .

From each of these 8 completely walled embryo initials (fig. 5) an embryo develops by means of an apical cell, this cell functioning first as a hemispherical apical cell of one cutting face, and later as a semi-pyramidal cell of 3 cutting faces, in a manner described in greater detail elsewhere (3). It may be added that this apical cell persists until an embryo mass of about 500 cells has been formed, after which it is replaced by the meristematic group of cells found in the older conifer stem tip. This apical cell is a primitive feature in which conifers recapitulate their fern phylogeny.

The EARLy EMBryo of PinUs.-The cells $(p)$ of the embryo initial undergo simultaneous division, in which their first apical 
cell segments $(s)$, the primary suspensor cells, are cut off. This group constitutes what has generally been recognized as the suspensor tier of the r6-celled stage (cf. figs. 5, 6). Next the suspensor cells $(s)$ elongate and thrust the embryonal tier of apical cells into the pocket which the digestive enzymes of the eggs and embryos have corroded within the gametophyte, the 4 embryo units separating and their apical cells (a) continuing to give rise to segments $\left(e_{1}, e_{2}\right.$, etc.), which elongate and add to the suspensor.

Soon the rosette group of initials divides and the development of the rosette embryos is begun ( $q$, fig. 8 ). It will be seen, therefore, that not only do these 8 embryos per zygote all result from free nuclear cleavages, but the several embryos develop independently from the time the first walls are organized. The primary embryos develop without interruption from their initials, while the rosette embryos are delayed, developing somewhat later, on an average, than is indicated in fig. 8. In the hundreds of instances that have been examined in my investigations of various pines, none were found where the 4 primary embryos were combined to produce a single embryo, nor were any cases found where one of the primary em-

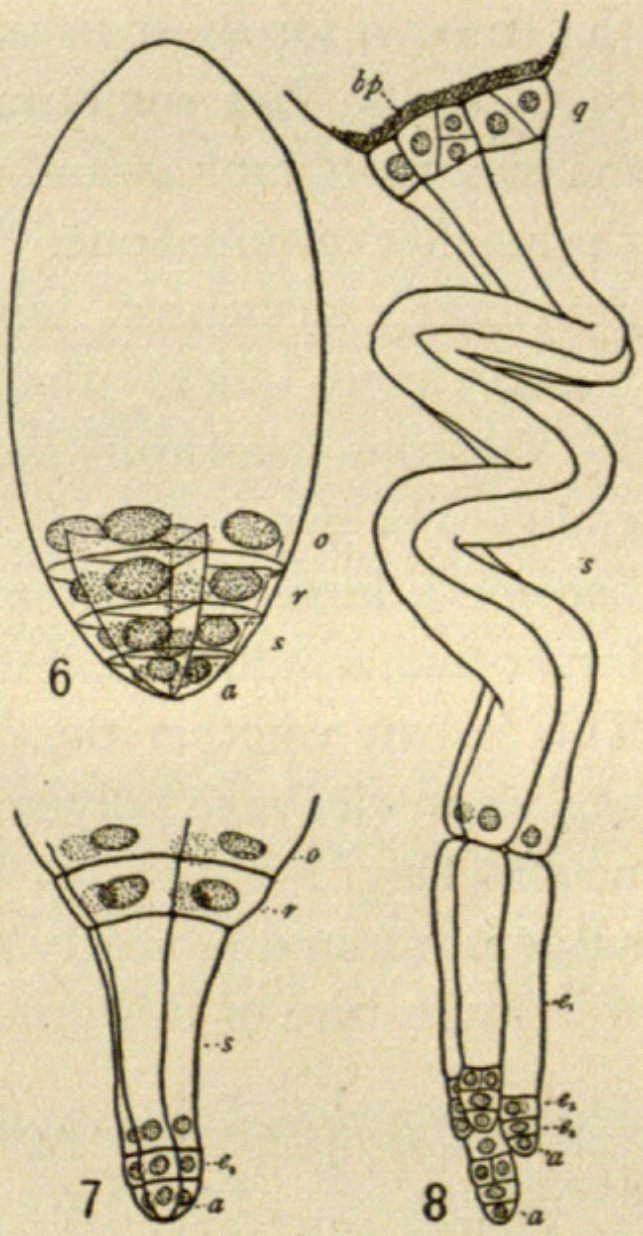

Figs. 6-8.-Stages in development of early embryo in Pinus: $a$, apical cells; $s$, primary suspensor cells; $r$, rosette cells; which give rise to $q$, rosette embryos (latter usually develop later than in stage of embryo shown); $e_{1}, e_{2}$, etc., embryonal tube initial cells and embryonal tubes, which elongate and add to suspensor; diagrammatic reconstructions.

bryos was further split up to give rise to 2 or more embryos.

In the competition which ensues, the rosette embryos play a very subordinate rôle, owing to their unfavorable position and delayed development. Among the 4 primary embryos, the competitive process elects one embryo from the complex, nearly always the embryo which develops the longest suspensor, pushing it ahead of 
its competitors. Embryonic vigor in producing a long suspensor is the outstanding factor which decides upon the successful embryo. The mass of embryonal tubes which elongate from the base of the embryo, as this and the suspensor become more massive, doubtless assist the successful embryo in checking the others. Usually it is the embryo foremost in position which is successful in developing to maturity, but sometimes the second one in position becomes massive more rapidly and assumes the leading rôle, by choking out the smaller terminal one. Not only must an embryo have a rapidly developing suspensor, but it must also become many-celled and massive more quickly than any of the competing embryos.

Vigorous suspensors have been the basis of selection among the embryos of gymnosperms for so long a period that this organ has become a large and extensively developed structure, many times larger than would be necessary without this embryonic competition. This is true whether the competing embryos come from the same egg, as in cleavage polyembryony, or the selection occurs between neighboring zygotes, as among cycads. The remarkably long suspensor found in nearly all gymnosperms has always been a noteworthy feature of this group.

\section{Investigation}

OTHER PINE SPECIES.-The result of a further investigation of the embryo development in various species of pines confirmed the account as announced for Pinus (3). The additional work done on Pinus Strobus, $P$. ponderosa, $P$. edule, and $P$. resinosa, as well as a further examination of $P$. Laricio, $P$. Banksiana, and $P$. sylvestris, makes it practically certain that cleavage polyembryony, the apical cell development, and the rosette embryos are found quite constantly among all members of this genus.

It might be noted that Pinus sylvestris seems to have a marked tendency to produce shorter suspensor cells and embryonal tubes than $P$. Banksiana, which was taken as the type for the previous investigation. In $P$. Laricio the 4 primary embryo units frequently do not split apart until the primary suspensor cells have stretched to about half their final length and the first embryonal tubes are beginning to elongate. Indeed, when some of these earlier stages 
were examined, the writer's prediction was that in this species, at least occasionally, the usual separation into 4 primary embryos did not occur, but hundreds of embryos dissected out in slightly later stages (several days older) of material from the same source failed to reveal even one case without the usual cleavage polyembryony.

The rosette embryos of Pinus Laricio are very clear. In many cases they have suspensors which elongate distinctly, and were it not for the fact that the dissections clearly show their relation to the basal plate $(b p)$, these rosette embryos would in some instances very easily be confused with the primary embryos. On the whole, the embryos of $P$. Laricio furnish probably the most satisfactory type for use in laboratory instruction, both on account of their clearness in displaying the rosette embryos, and their large size, which makes them easier to dissect.

AbIETineae. - The other genera of Abietineae that were dissected and examined are Cedrus libani, Tsuga canadensis, Abies balsamea, Picea mariana, Picea excelsa, Larix europea, and Pseudotsuga taxifolia, the species investigated representing 7 out of the 9 genera of the Abietineae.

Method and Material. - The technique was that of dissection described in detail in the writer's work on Pinus. No modifications of these methods were found necessary, but perhaps it should be repeated that the living material is indispensable for some species. A study of preserved material is possible, but it is not so satisfactory. The embryos may be killed and preserved indefinitely, however, after they have been removed by the methods described. The proembryo stages must be studied by the well known methods for making serial sections. The writer is indebted to the following for the material used during the summer of I9I $_{7}$ : W. G. WATERMAN for material of Abies and Tsuga from Frankfort, Michigan; S. D. Magers for collections of Abies balsamea and Picea mariana from Marquette, Michigan; D. Hill Nursery Company, of Dundee, Illinois, for material of Pseudotsuga, Larix, and Tsuga canadensis, collected on their grounds. Very satisfactory material of Pseudotsuga taxifolia was supplied by the Friday Harbor Marine Station of Puget Sound. During June and July C. T. Hilmers supplied 
weekly collections of the material growing on the University Farm near Lincoln, Nebraska, as follows: Picea excelsa, Pseudotsuga taxifolia, Pinus ponderosa, $P$. sylvestris, $P$. Laricio, and $P$. Strobus. In addition to this, the writer made many trips to various places in the vicinity of Chicago to secure material of some of these same species. During the summer of 1918, W. W. RoBbins supplied a collection of Pseudotsuga taxifolia from near Fort Collins, Colorado, and arranged for a collection of Pinus edule from Cortez, Colorado; and E. J. Kraus made several collections of the cones of Cedrus libani from the grounds of the Oregon Agricultural College, Corvallis, which reached the writer in excellent condition.

Cedrus has almost the same early embryogeny as Pinus. The primary embryos, however, do not separate until some time after the suspensor cells and first embryonal tubes have both elongated, and therefore cling together very much longer than in any species of Pinus that was investigated. In all the slightly older stages the embryo units had separated, indicating that cleavage polyembryony is likewise a constant feature in Cedrus. An apical cell stage seems to exist in this genus, and rosette embryos usually occur, somewhat less developed than in the average pine. The older suspensor cells collapse soon after separation of the primary embryo units.

Tsuga canadensis also resembles Pinus very much in its embryogeny. In this species the embryo units separate into the 4 primary embryos, yet they cling together longer than in any pine, apparently about as long as in Cedrus. Cleavage polyembryony occurs regularly. This conclusion is based upon the careful dissection and examination of the embryos of about 40 ovules of a more advanced stage, among which no exceptions were found.

Save for their difference in size, Tsuga,Cedrus, and Pinus appear very similar in the first stages of suspensor formation. In Tsuga, however, the rosette cells are very ephemeral; they were not found to divide before the collapse and disintegration of their contents, apparently giving no rosette embryos. The suspensor cells also collapse very soon in Tsuga, leaving only a shred of tissue which connects the shriveled rosette to the embryo system below. As in Pinus, the early embryos develop by means of an apical cell. 
There are from two to four archegonia present in Tsuga, and in the material studied one or two embryo systems was the usual number found. The cones were very poorly pollinated, and doubtless the normal maximum number did not occur. Polyembryony, although extensive, is much less pronounced than in Pinus, for in addition to the small number of archegonia, there are no functioning rosette embryos.

In Abies the normal product of a fertilized egg is a single embryo. The group of rosette cells is present, and in a few rare instances a divided rosette cell and a more advanced rosette embryo were found. This, as well as the fact that cleavage polyembryony was also observed in a few cases, shows that this genus stands next to Cedrus and Tsuga in its similarity to Pinus.

The apical cell stage is doubtless eliminated from the beginning, for when under normal conditions all of the lower tier of cells combine to produce a single embryo, the terminal cells together are responsible for producing the tissue. It appears also from an examination of some of the early embryos that these 4 terminal cells of the apical group do not always contribute equally to the cell mass, for one of these 4 terminal cells may frequently be found decidedly more prolific than the others. Normal apical cell growth, however, is not possible unless cleavage polyembryony occurs, as it rarely does.

The suspensor cells and upper embryonal tubes of the secondary suspensor collapse very soon after elongation. The basal plate $(b p)$, a deposit formed within the egg over the rosette cells, is very thick and frequently obstructs a clear view of the rosette cells, which also collapse early, unless a rosette embryo happens to develop.

The material of Picea was somewhat limited. The cones that could be secured of $P$. mariana were younger than the fertilization stage, and a later collection was too old for a satisfactory study of the early embryo. A number of twigs bearing cones from the first collection were kept in a tin box in the laboratory for more than a week, and at the end of this time they were found to contain embryos in the desirable stages. The $P$. excels $a$ cones were very poorly pollinated, and only a few good embryos were secured from 
this species. A study of this material makes it clear that cleavage polyembryony does not occur, but each archegonium produces only a single embryo. The group of rosette cells is present, but no divisions were found within these cells producing rosette embryos, as they do occasionally in Abies. Picea, therefore, is a step farther removed from Pinus in having eliminated all traces of cleavage polyembryony and rosette embryos, except the tier of rosette cells.

Although the available material of Larix was also somewhat limited, several outstanding features may be described with certainty. Like Picea and Abies, only one embryo is produced per archegonium. Except for the different appearance in size and proportion, the embryo of Larix is very similar to that of Picea. The 4 collateral primary suspensor cells become very long and slender, without the abrupt twists or turns found in the pine suspensor, and the secondary additions of the suspensor have similar characteristics. The older divisions of the suspensor collapse as the newer embryonal tubes elongate from the base of the embryo. A group of rosette cells is present, but these collapse without forming embryos, and the basal plates are again large, obstructing a good view of the former in many cases.

Pseudotsuga furnishes a rather interesting variation from the embryos already described. This form is like Picea and Larix in producing only one embryo from each egg. It has no rosette cell, but the uppermost tier of walled cells elongates to form the suspensor, a condition shown in less than 5 per cent of the pine embryos (Pinus Banksiana). This occurs as a regular feature in Thuja (12) and many other conifers. As the suspensor elongates, the contents of the archegonia shrink and harden, and persist as flattened, deeply stained structures attached to the upper ends of the transparent suspensors. A very thick layer of protoplasm or other substance, in the position which corresponds to the basal plate, stains more deeply than the remaining regions of the withered archegonia. Although cleavage polyembryony does not occur, a larger number of embryos is produced than in Abies, Larix, or Picea. This is due to the existence of a larger number of archegonia, which range from 5 to 8. The suspensor cells do not collapse early, as in Larix and Abies, and although the embryos were never found splitting into 
separate units, the suspensor cells back of the embryo become easily separated from each other.

\section{Discussion}

It will be seen that among the 7 genera of the Abietineae examined, the last three do not possess cleavage polyembryony even as an occasional feature, while in Abies it occurs only in rare instances. Likewise the rosette embryos occur normally in Pinus

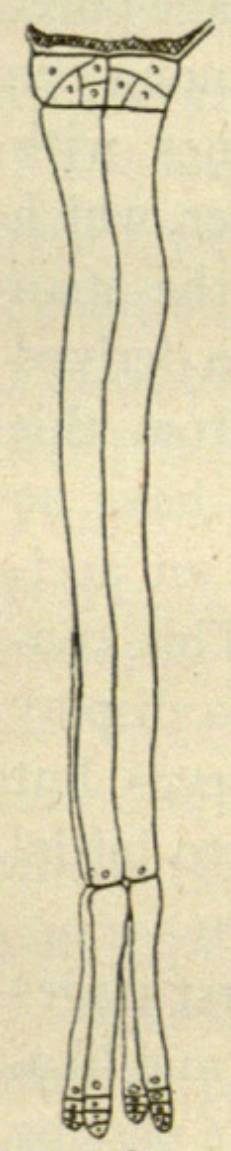

9

Pinus

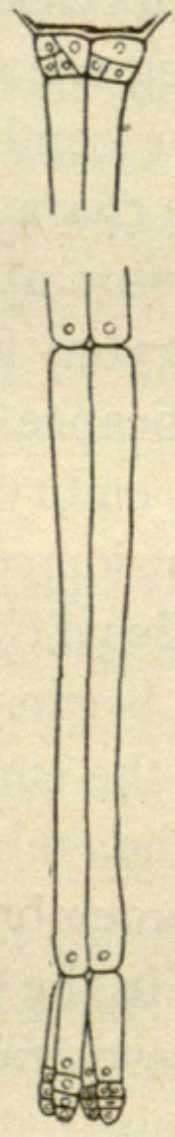

10



11

Cedrus

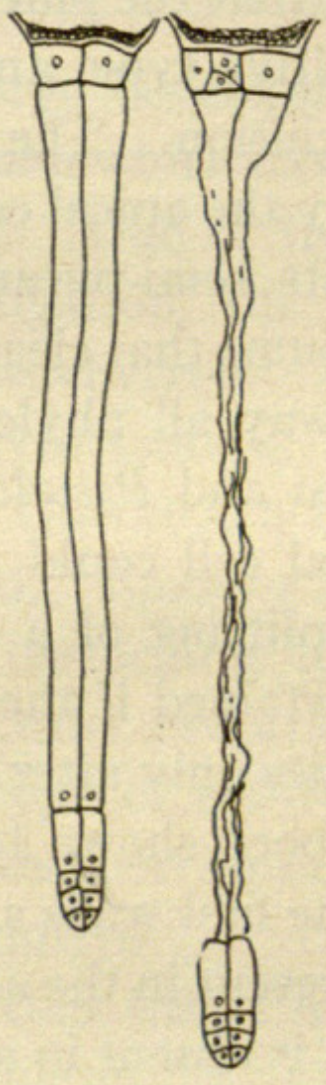

12

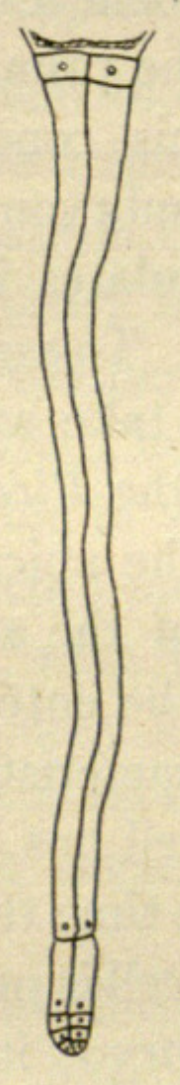

13

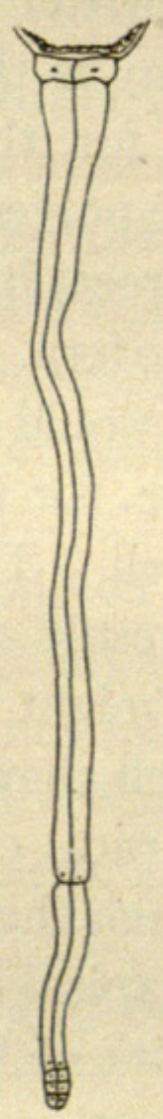

14

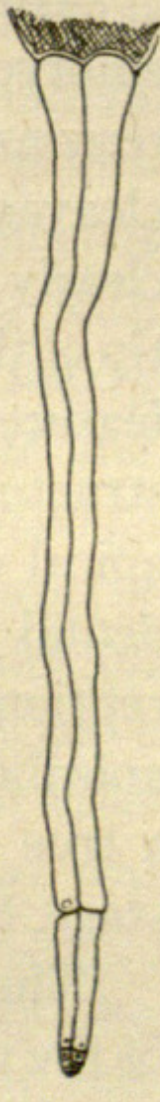

15

Picea Larix Pseudo-

FIGS. 9-I5.-Embryos of 7 genera of Abietineae, showing intergrading series with cleavage polyembryony on the one hand (figs. 9-II) and its absence on the other (figs. I 2-r 5); rosette embryos in Pinus, Cedrus, and occasionally Abies; diagrams not drawn to scale.

and Cedrus, and only rarely in Abies, while none of the other forms shows them even occasionally. Cedrus and Tsuga are most like Pinus in possessing cleavage polyembryony as a constant feature, but in the latter the rosette cells do not produce rosette embryos. Rosette cells, even though they produce no embryos, as in Tsuga, Larix, and Picea, are clearly homologous with these embryo initials in Pimus and Cedrus, and represent vestigial structures wherever they are present. Figs. 9-15 illustrate these differences. We have 
here a very interesting intergrading series, with Pinus at one end and Pseudotsuga at the other. There seem to be but two alternatives; either the Picea or Pseudotsuga type of embryo has given rise to the Pinus type with cleavage polyembryony, or the Picea embryo is composite in its origin, being made up of the fused or combined elements that produce the many cleavage embryos in Pinus.

The writer believes that the pine embryo with its cleavage polyembryony is the primitive type, and the following are among the reasons for this conclusion. The pine embryo combines with cleavage polyembryony the apical cell, a primitive character, which clearly recapitulates its semi-pyramidal predecessor at the stem tip of the fern. To assume that cleavage polyembryony is a derived feature would take away all phylogenetic significance from this structure, for the Picea and Pseudotsuga type of embryo have no apical cell. The apical cell could hardly be considered an accidental result of the splitting of a Picea-like embryo. This conception might be entertained if the terminal cell began to display apical cell characteristics only after separation of the embryos, but a true apical cell has been shown to exist from the embryo initial stage, from the time the first walls appear in the proembryo.

The apical cell is present in the adult ferns and in the first stages of the pine embryo; it is absent in all adult gymnosperms and likewise in angiosperms. This structure has been eliminated in passing from the lower to the higher vascular plants, and in Picea, Larix, and Pseudotsuga the apical cell is entirely eliminated from the beginning of the life history. The embryo development in this group shows how the apical cell was lost in the evolution of the Abietineae.

Another reason why the Pinus embryo must be considered the more primitive type arises from the study of the rosette embryos. In the Picea embryo are found the vestigial rosette cells, which never divide, but are clearly homologous with the rosette embryo initials in the pine. Even in the pine these rosette embryos are vestigial, but since these rudimentary structures are well developed in the latter, one would infer that the Pinus type represents the more primitive condition. 
Another point in favor of the view that cleavage polyembryony is a primitive feature is the fact that Pinus is known to be very old historically. This genus has come to be regarded by paleobotanists as one of the very oldest conifers (6). On the other hand, Jeffrey (9, Io) has reached this same conclusion on the basis of anatomy.

An additional argument that cleavage polyembryony is primitive comes from a consideration of the relation that the pine embryo holds to the known steps in the embryo development of other conifers. There are several lines of evolution which have arisen from a primitive type of embryo like Pinus. One of these is the abietineous evolution shown in this investigation, the series beginning with Pinus and culminating in Pseudotsuga. Another evolutionary series begins with Pinus, involves some of the Cupressineae and Taxodineae, and culminates in Gnetales, a line in which cleavage polyembryony has been retained. Ephedra has a modified form of cleavage polyembryony, which associates it with Coniferales on the basis of its embryogeny. Other evolutionary lines may have been derived from the Pinus type of embryo, as described elsewhere (3). This is therefore another strong argument that the pine type of embryo is very primitive.

Strasburger (I8) has reported that Picea develops only one embryo per archegonium, and his results are thus verified by this study, but he did not attach any significance to the question of whether or not a separation of the embryos occurs. Other investigators in dealing with the embryos of the Abietineae have likewise failed to make this point clear, and the embryogenies of some genera, such as Cedrus, Tsuga, Abies, and Larix, have been partially investigated in proembryo stages only.

The proembryo of Pinus has been most extensively studied, described, and figured by Chamberlatn (4), Coulter and Chamberlain (5), Miss Ferguson (7), and Miss Kildahl (II), each investigator adding a few additional.stages and details. The facts brought out by these investigators are in harmony with the interpretation given to the proembryo in this paper.

The embryogeny of conifers has not usually been undertaken by morphologists as a distinct problem, but the stages described and 
figured were often rather incomplete, being only the by-product of another investigation. In several instances the proembryo of other Abietineae has been described as being the same as Pinus, but it is doubtful if all of the investigators verified every step of the embryogeny included in their account. Four tiers of 4 cells (fig. 6) may be produced by several methods of division.

Lawson (13) describes 4 tiers of 4 cells each for Pseudotsuga, but since this species has no rosette group, the exact order of division and the stages corresponding to figs. $4^{-7}$ in Pinus may not be the same. The writer has not had opportunity to examine the proembryo or the earliest stages of the embryo in this species, but it may be inferred that one of two things happens in the Pseudotsuga embryo. Either the lowest tier, shown for Pinus in fig. $4 p$, continues to divide to give rise to the additional two tiers of cells, or, more probably, the exact order of division shown in Pinus is carried out, and it is the rosette tier which elongates. Pinus Banksiana (3) was found with elongated rosette cells in nearly 5 per cent of the cases studied. It is very important, therefore, to know whether the divisions that occur in the proembryo of any species are homologous with those of Pinus.

Mryake (14), in his study of Picea, includes the stages of the proembryo, and fortunately he figured a stage between fig. 4 and fig. 5 , also between fig. 5 and fig. 6 , which proves that the rosette tier found in this form is identical in origin with that of Pimus, and the rosettes of these two species are therefore distinctly homologous.

Tsuga and Abies probably have proembryos identical with Pinus, in view of the results shown for Picea. Only a few stages of the proembryo in Tsuga canadensis are definitely known. These were figured by MURRILL ( 17 ) as essentially the same as Pinus, but not illustrated in stages older than fig. 3. Abies balsamea was shown by Mryake (15) to be practically the same as Pinus for the stages up to and including fig. 4. In view of the similarity of Pinus and Cedrus in their early embryogeny, there can be little doubt that the proembryo of the latter develops in very much the same manner.

Only two genera of the Abietineae have not been investigated in some early stage by the writer. These are Keteleeria and Pseudo- 
larix. The later embryo and other anatomical features of Keteleeria are described by Hutchinson (8), but the early embryo still remains to be studied. Pseudolarix was described by Mryake and YASUI (16), whose work shows stages in the embryo similar to figs. 2,4 , and 6 , with a figure showing the suspensor cells beginning to elongate. This species has rosette cells and appears more slender, but is otherwise like the average of the Abietineae in the same stage of development before the embryo units separate (if they do). This embryo is not like Pseudotsuga, therefore, but probably belongs somewhere in the series (figs. 9-I5) between Tsuga and Picea, the exact position depending upon whether or not cleavage polyembryony occurs, and whether the rosette cells give rise to rosette embryos.

Some taxonomists include Pseudotsuga in the same genus with Tsuga. The results of this investigation show that, on the basis of the embryogeny at least, there is a fundamental difference between these two forms, which would entitle Pseudotsuga to be recognized as a separate genus. The contrasting differences may be summarized as follows. Tsuga has cleavage polyembryony and apical cell growth in its life history, while Pseudotsuga has none of these features; and while the rosette cells do not produce embryos in Tsuga, they are either entirely absent in Pseudotsuga or they elongate to form the suspensor and are not recognizable. The latter genus has also $5^{-8}$ archegonia, while Tsuga usually has a smaller number $(2-4)$.

It should be noted that the difference between the embryo of Pseudotsuga and Tsuga is greater than that between Abies, Larix, and Picea, and much greater than that between Pinus and Cedrus. Cedrus, on the other hand, shows little in its early embryogeny which would entitle it to a place as a separate genus, but the difference between Pinus and Cedrus is nearly as great as that between Larix and Picea.

\section{Summary}

I. Although all species of Pinus have shown a complete separation of the 4 primary embryos, this feature of cleavage polyembryony is not characteristic of all Abietineae. 
2. The cleavages which separate the 8 embryos from each other are the free nuclear divisions of the proembryo. In forms without cleavage polyembryony (Picea, and as far as we know concerning other forms), cell divisions homologous with those in Pinus occur in the proembryo.

3. The embryos of the Abietineae may be arranged in an intergrading series, with Pinus at one end and Pseudotsuga at the other, on the basis of the occurrence of cleavage polyembryony, rosette embryos, and the apical cell. The rosette embryos and their vestiges, the rosette cells, are gradually eliminated as we pass from Pinus to Pseudotsuga.

4. Cleavage polyembryony, rosette embryos, and the apical cell mark a primitive type of embryo development.

5. The embryo development of this group shows how the apical cell was lost in the evolution of the Abietineae.

6. On the basis of embryogeny Pseudotsuga is unique and is entitled to rank as a separate genus.

This study was begun at the Hull Botanical Laboratories in the summer of 1917 and is the result of a preliminary study of the embryo material of these conifers. More detailed descriptions of the embryos with illustrations will appear later. The writer takes pleasure in acknowledging his indebtedness to Dr. C. J. Chamberlain for valuable council in getting this investigation under way.

UNIVERSITY OF ARKansas

Fayetteville, Ark. 


\section{LITERATURE CITED}

r. BRown, R., in Capt. Philip P. King's "Survey of the western and intertropical coasts of Australia," London, 1826, Appendix B, p. 557 ; also Ann. Sci. Nat. I 8:211. I826.

2. - - Plurality and development of embryo in the seeds of Coniferae. Rep. Brit. Assoc. Adv. Sci. I835: 596, 597; reprinted in Ann. Sci. Nat. II 20: 193 . I843; same paper reprinted with postscript and plate, Ann. Nat. Hist. 13: $138-374$. 1844 .

3. Buchнolz, J. T., Suspensor and early embryo of Pimus. Bот. Gaz. 66: I85-228. pls. 6-Io. figs. 3. I918.

4. Chamberlain, C. J., Oogenesis in Pinus Laricio. Bot. Gaz. 27:268-280. pls. 3. 1899 .

5. Coulter, J. M., and Chamberlain, C. J., Morphology of Spermatophytes. Part I. Chicago. I90I.

6. -- , Morphology of gymnosperms. Chicago. I9ro.

7. Ferguson, Margaret C., Contributions to the life history of Pinus, with special reference to sporogenesis, the development of the gametophytes, and fertilization. Proc. Wash. Acad. Sci. 6:I-202. pls. I-24. 1904.

8. Hutchinson, A. H., Morphology of Keteleeria Fortunei. Bот. Gaz. 63: I 24-I35. pls. 7,8 . I9I 7 .

9. Jefrrey, E. C., The comparative anatomy of the Coniferales II. The Abietineae. Mem. Boston Soc. Nat. Hist. 6:1-37. pls. I-7. 1904 .

ro. - - , The anatomy of woody plants. Chicago. I9I7.

Ir. Kildahl, N. Johanna, Development of walls in the proembryo of Pimus Laricio. Bот. GAZ. 44:102-107. pls. 8, 9. 1907.

12. LAND, W. J. G., A morphological study of Thuja. Bот. GAz. 34:249-259. pls. 6-8. 1902 .

13. Lawson, A. A., Gametophytes and embryo of Pseudotsuga Douglasii. Ann. Botany 23:163-180. pls. 12-14. 1909.

14. Mryake, K., On the development of the sexual organs and fertilization in Picea excelsa. Ann. Botany 17:351-352. pls. 4. 1903.

15. - - , Contributions to the fertilization and embryogeny of Abies balsamea. Beih. Bot. Centralbl. 14:134-I44. pls. 6-8. 1903.

16. Mryake, K., and YASUI, Kono, On the gametophytes and embryo of Pseudolarix. Ann. Botany 25:639-647. pl. 48. I9ri.

17. MURRILL, WM. A., Development of the archegonium and fertilization in the hemlock spruce (Tsuga canadensis Carr.). Ann. Botany 14:583-607. pls. 31,32 . 1900 .

18. Strasburger, E., Die Coniferen und Gnetaceen. Jena. I872. 


\section{$2 \mathrm{BHL}$ Biodiversity Heritage Library}

Buchholz, J. T. 1920. "Polyembryony Among Abietineae." Botanical gazette 69(2), 153-167. https://doi.org/10.1086/332623.

View This Item Online: https://www.biodiversitylibrary.org/item/109453

DOI: https://doi.org/10.1086/332623

Permalink: https://www.biodiversitylibrary.org/partpdf/224539

\section{Holding Institution}

Missouri Botanical Garden, Peter H. Raven Library

\section{Sponsored by}

Missouri Botanical Garden

\section{Copyright \& Reuse}

Copyright Status: Public domain. The BHL considers that this work is no longer under copyright protection.

This document was created from content at the Biodiversity Heritage Library, the world's largest open access digital library for biodiversity literature and archives. Visit BHL at https://www.biodiversitylibrary.org. 